\title{
Cytotoxic and antigenotoxic properties of phenolic compound isolated from the fruit of Terminalia chebula on HeLa cell
}

\author{
K. Soumya, Jesna James, T. M. Archana, A. T. Dhanya, A. P. Shahid and S. Sudheesh * (D)
}

\begin{abstract}
Background: DNA in a human cell is subjected to constant assault from both environmental factors and normal metabolic processes. Accumulation of DNA damage drives the progression of many health disorders like aging, cancer, diabetes, and neurodegenerative disorders.

Results: The present study focuses on the isolation of phenolic compound from the fruit of Terminalia chebula and its protective role on induced DNA damage. Diethyl ether and ethyl acetate extract of Terminalia chebula fruit were subjected to column chromatographic purification, and the fractions obtained were tested for the presence of phenolics. Fraction-12 isolated from diethyl ether extract was identified as gallic acid, which is used for cytotoxic and DNA damage protection activity assays. To select a non-toxic concentration of isolated compound, cytotoxicity was assessed by MTT assay. Gallic acid showed moderate toxicity at the highest concentration tested (i.e., percentage cell viability at $100 \mu \mathrm{g} / \mathrm{ml}$ is $40.51 \pm 1.31$ ). Antigenotoxic effect of gallic acid on HeLa cells was carried by alkaline comet assay. The compound showed significant protective abilities against hydrogen peroxide-induced DNA damage in HeLa cells.
\end{abstract}

Conclusion: These results show the importance of gallic acid isolated from Terminalia chebula fruit, as protector of oxidative stress-induced DNA damage.

Keywords: Terminalia chebula, Cytotoxicity, Antigenotoxicity, HeLa cell

\section{Background}

DNA is the essential carrier of genetic information in living organisms, which contains all genetic information needed for the growth, development, reproduction, and ultimately death of the organism. Even though DNA is stable and versatile, it undergoes several types of spontaneous changes and may lead to damage in DNA. It occurs at a rate of 10,000 to $10,00,000$ lesions per cell per day. DNA itself has many elaborate mechanisms to solve the damages. DNA damage, if not repaired properly, may lead to genomic instability, mutation, aging, cancer, and several other diseases.

Oxidation is a natural cellular metabolic process which results in the formation of free radicals known as reactive oxygen species (ROS) or reactive nitrogen species (RNS). Common examples are peroxyl radical $\left(\mathrm{RO}_{2} \cdot\right)$,

\footnotetext{
* Correspondence: sudheeshs@knruty.ac.in

School of chemical Sciences, Kannur University, Payyanur campus, Edat P. O., Payyanur, Kannur, Kerala 670327, India
}

hydroperoxyl $\left(\mathrm{HO}_{2} \cdot\right)$, superoxide $\left(\mathrm{O}_{2}^{-}\right)$, hydroxyl $(\mathrm{OH})$, nitrogen dioxide $\left(\mathrm{NO}_{2} \cdot\right)$, free radicals, etc. [9]. Once formed, they initiate a chain reaction by reacting with other molecules in their vicinity to attain stability. Excessive production of free radicals causes an imbalance between the generation of ROS and the antioxidant enzymes, which can lead to oxidative stress and damage to biological molecules such as DNA, protein, and lipids.

Phenolics are claimed to protect against many health disorders like cancer, diabetes, cardiovascular diseases, and aging, mainly by preventing initial DNA damages. Recently, there are many methods available for the estimation of DNA damage and repair like bacterial Ames test, the scoring of chromosome aberration, and micronuclei and sister chromatid exchanges $[1,16]$. Among these classical techniques, single cell gel electrophoresis assay or comet assay is a widely accepted and commonly used technique. Comet assay is a rapid, inexpensive, short-term screening technique developed to study the antigenotoxic potential of natural compounds [22]. The 
assay can be carried out at neutral $\mathrm{pH}$ or high $\mathrm{pH}$ (above $\mathrm{pH}$ 13). At neutral $\mathrm{pH}, \mathrm{DNA}$ migration is due to the presence of double-strand breaks, while at alkaline $\mathrm{pH}$, DNA migration is associated with the presence of single-strand breaks, alkali labile sites, and single-strand breaks associated with incomplete excision repair sites [17]. The alkaline version is more acceptable since it allows the detection of a wide range of damages. Comets are scored, either by computer-based image analysis software or by visual scoring to calculate tail length, \% tail DNA, which are the most appropriate parameters to be taken into account for the study.

Comet assay normally requires a supercoiled cellular genomic DNA of any cell line which is not proliferating, which can be made into single-cell suspension [12]. Therefore, HeLa cell line was chosen for this study. Hydrogen peroxide was selected to elicit oxidative stress, since it is freely diffusible and can potentially reach the nucleus to interact with DNA and cause damage to DNA by generating hydroxyl radical, $\cdot \mathrm{OH}$. These highly reactive hydroxyl radical causes strand breaks and base damage in DNA. It also modifies purine and pyrimidine and causes significant production of DNA base damage products, 8-OH-Gua, FapyGua, etc. [4].

In the present study, the antigenotoxic activity of gallic acid, a phenolic compound isolated from Terminalia chebula, on hydrogen peroxide-induced DNA damage in human cervical cancer cell line (HeLa) was investigated by comet assay.

\section{Methods}

\subsection{Preparation of extracts}

Fresh fruits of Terminalia chebula were collected from Kannur district of Kerala, India, and were taxonomically identified by Dr. Sujanapal P, Scientist, Kerala Forest Research Institute (KFRI), Thrissur, Kerala, India. They were washed with running water followed by double-distilled water. It was air-dried in the dark and was powdered coarsely. Shade-dried fruit powder of the plant was weighed and extracted with $80 \%$ methanol using the Soxhlet method, for $24 \mathrm{~h}$. The methanol extract was decanted, and the extract was filtered through Whatman filter paper No 1. The solvent extract was concentrated, and the dried extract was stored at $4{ }^{\circ} \mathrm{C}$ for further analysis.

\subsection{Extraction and isolation of phenolics from Terminalia chebula}

Eighty percent of methanolic extracts were washed with petroleum ether to remove fatty matter. The filtrate was partitioned with diethyl ether and ethyl acetate. Diethyl ether and ethyl acetate fractions were concentrated by vacuum oven and further subjected to column chromatographic purification. The column was eluted with hexane to ethyl acetate and ethyl acetate to methanol in varying ratios [20]. Fractions of $20 \mathrm{ml}$ with each solvent system were collected and were analyzed by TLC. The fractions showing similar Rf values were pooled together and concentrated in vacuum to isolate the active principles. All the pooled fractions were tested for the presence of phenolics.

\subsection{Tests for phenolics \\ 2.3.1 Ferric chloride test}

The sample was treated with few drops of ferric chloride solution; the formation of bluish-black color indicated the presence of phenolic compounds.

\subsection{Structural characterization of the compound}

Many fractions showing positive results for phenolics were collected and were also subjected to in vitro antioxidant activity studies. The active fraction which showed the highest antioxidant activity was selected for further structural elucidation. The chemical structure of the isolated compound was determined by proton nuclear magnetic resonance spectroscopy $\left({ }^{1} \mathrm{H}\right.$ NMR) and mass spectroscopy. NMR spectra were taken on a Bruker Ascend 500 $\mathrm{MHz}$ spectrometer for ${ }^{1} \mathrm{H}$ NMR and $125 \mathrm{MHz}$ for ${ }^{13} \mathrm{C}$ $\mathrm{NMR}$. The spectra were recorded using $\mathrm{CD}_{3} \mathrm{COCD}_{3}$ (deuterated acetone) as solvent and TMS (tetramethyl silane) as the internal standard. Mass spectrum of the purified compound was recorded on a Thermo Fisher Scientific high-resolution mass spectrometer (HRMS).

\subsection{Cytotoxicity of phenolic compound isolated from diethyl ether extract of Terminalia chebula towards HeLa cell line}

Cytotoxicity of isolated phenolic compound from diethyl ether extract of Terminalia chebula fruit towards HeLa cell lines was evaluated by MTT assay. Initially, cervical cancer cells line HeLa was obtained from NCCS, Pune, India, and maintained in DMEM (Sigma Aldrich, USA) supplemented with L-glutamine, 10\% FBS, sodium bicarbonate, penicillin $(100 \mathrm{U} / \mathrm{ml})$, streptomycin $(100 \mu \mathrm{g} / \mathrm{ml})$, and amphotericin B $(2.5 \mu \mathrm{g} / \mathrm{ml})$. Cells were cultured in $25 \mathrm{~cm}^{2}$ tissue culture flasks and kept at $37{ }^{\circ} \mathrm{C}$ in a humidified 5\% $\mathrm{CO}_{2}$ incubator (NBS Eppendorf, Germany). Sub-culturing of the cells was performed by trypsinization, and the cells were maintained in DMEM. The experiment was repeated twice in triplicates.

$2 \times 10^{3}$ cells were seeded in a 96-well plate and incubated for $24 \mathrm{~h}$. After $24 \mathrm{~h}$ treatment, the cells were treated with different concentrations of extracts. Untreated cells served as negative control, and the cells were incubated for $24 \mathrm{~h}$ at $37^{\circ} \mathrm{C}$ and $5 \% \mathrm{CO}_{2}$. At the end of the opted time of incubation, $10 \mu \mathrm{l} \mathrm{MTT}(5 \mathrm{mg} / \mathrm{ml})$ was added to each well and the plates were incubated for $4 \mathrm{~h}$. Supernatants were removed, and the resultant formazan crystals formed were dissolved in $100 \mu \mathrm{l}$ DMSO. The extent of MTT reduction was measured at $590 \mathrm{~nm}$ with reference wavelength at $620 \mathrm{~nm}$ using 
a microwell plate reader [2, 21]. All absorbance values were corrected against blank wells which contained growth media alone. For each test concentration, the mean absorbance of the triplicated wells was noted. Mean absorbance of the cells grown in the absence of test compound was taken as $100 \%$ cell survival.

Percentage cell viability was calculated by using the following formula:

$$
\% \text { Cell viability }=\frac{\text { Absorbance of sample } \times 100}{\text { Absorbance of control }}
$$

2.6 In vitro antigenotoxic activity of phenolic compound isolated from Terminalia chebula fruit by comet assay Initially, the cell lines (cervical cancer cell HeLa) were obtained from NCCS, Pune, India, and maintained in DMEM (Sigma Aldrich, USA) supplemented with L-glutamine, 10\% FBS, sodium bicarbonate, penicillin $(100 \mathrm{U} / \mathrm{ml})$, streptomycin $(100 \mu \mathrm{g} / \mathrm{ml})$, and amphotericin B $(2.5 \mu \mathrm{g} / \mathrm{ml})$. Cells were cultured in $25 \mathrm{~cm}^{2}$ tissue culture flasks and kept at 37 ${ }^{\circ} \mathrm{C}$ in a humidified $5 \% \mathrm{CO}_{2}$ incubator (NBS Eppendorf, Germany). Sub-culturing of the cells was performed by trypsinization, and the cells were maintained in DMEM. The experiment was repeated twice in triplicates.

The cells were treated with the isolated compound for $1 \mathrm{~h}$ at $37{ }^{\circ} \mathrm{C}$. The concentration of compounds was chosen from the range of non-cytotoxic concentration as assessed by MTT assay. DNA damage was induced by $50 \mu \mathrm{M} \mathrm{H}_{2} \mathrm{O}_{2}$ for $15 \mathrm{~min}$ and incubated for $24 \mathrm{~h}$. The adherent cells were then trypsinized, centrifuged, and resuspended in ice-cold PBS and were mixed well with $50 \mu \mathrm{l}$ of $0.5 \%$ low melting point agarose (LMPA) at $\mathrm{pH}$ 7.4 at $40{ }^{\circ} \mathrm{C}$. Microscopic slides were cleaned using alcohol and cleared in flame. Then, the slides were frosted and coated with $1 \%$ normal melting point agarose (NMA) and stored at $4{ }^{\circ} \mathrm{C}$. $1.6 \mathrm{ml}$ sample was immediately pipetted onto a frosted glass slide pre-coated with a layer of $1 \%$ normal melting point agarose prepared in PBS and covered with a glass coverslip. The agarose was immediately placed in a refrigerator for $5 \mathrm{~min}$ to allow complete agarose solidification. The coverslip was removed, and slides were immersed in a lysis solution (2.5 $\mathrm{M} \mathrm{NaCl}, 100 \mathrm{mM} \mathrm{Na}{ }_{2}$ EDTA, $10 \mathrm{mM}$ Tris, $\mathrm{NaOH}$ to $\mathrm{pH}$ 10 and $1 \%$ Triton $\mathrm{X}-100$ ) at $4{ }^{\circ} \mathrm{C}$ for $1 \mathrm{~h}$. DNA was allowed to unwind for $20 \mathrm{~min}$ in freshly prepared alkaline electrophoresis buffer $\left(1 \mathrm{mM} \quad \mathrm{Na}_{2}\right.$ EDTA, $\quad 0.3 \mathrm{~N}$ $\mathrm{NaOH}, \mathrm{pH}$ 13). The slides were then placed in a horizontal electrophoresis tank, and electrophoresis was performed at $12 \mathrm{~V} / \mathrm{cm}$ for $20 \mathrm{~min}$ at an ambient temperature of $4{ }^{\circ} \mathrm{C}$. The slides were then washed three times with $1 \times$ Tris for 5 min with neutralizing buffer (0.4 M Tris- $\mathrm{HCl}$ buffer, $\mathrm{pH} 7.4)$ before staining with $20 \mu$ l ethidium bromide $(20 \mu \mathrm{g} / \mathrm{ml})[10,13]$.

\section{Results}

\subsection{Structural elucidation of the compound}

\subsubsection{Appearance: White solid. Melting point: $250{ }^{\circ} \mathrm{C}$}

The following characteristic peaks are observed in the ${ }^{1} \mathrm{H}$ NMR spectrum (Additional file 1: Figure S1). Signals at $H=8.280,8.236$, and $7.152 \mathrm{ppm}$ and their related coupling constant represent protons at C-1, C-2, and C3 respectively. From the high-resolution mass spectrum (Additional file 2: Figure S2) of the isolated compound, it is clear that the base peak was observed at $\mathrm{m} / \mathrm{z}$ value of 170 coincidence with the molecular weight of gallic acid. The other peaks at $\mathrm{m} / \mathrm{z}$ values of 153,127 , and109 are due to the loss of acid and hydroxyl functional groups. ${ }^{13} \mathrm{C}$ NMR: $\delta \mathrm{C} 166.94$ (C-1), 145.14 (C-4 and C6), 137.79 (C-5), 121.20 (C-2), 109.1 (C-3 and C-7) (Additional file 3: Figure S3).

Based on the chemical and spectral analysis, and comparison with the literature [19], the structure of the isolated compound was elucidated as gallic acid, a phenolic acid (Fig. 1).

\subsection{Cytotoxic effects of gallic acid on HeLa cell by MTT assay}

To select a non-toxic concentration of isolated compound, the study of cytotoxicity was performed preceding the study of antigenotoxicity. The cytotoxicity was evaluated by MTT assay. For the MTT test, the following concentrations of the isolated compound at doses of $100,50,25,12.5,6.25,3.12,1.56$, and $0.78 \mu \mathrm{g} / \mathrm{ml}$ were tested. Percentage of cell viability was calculated in each concentration, and the results are shown in Table 1.

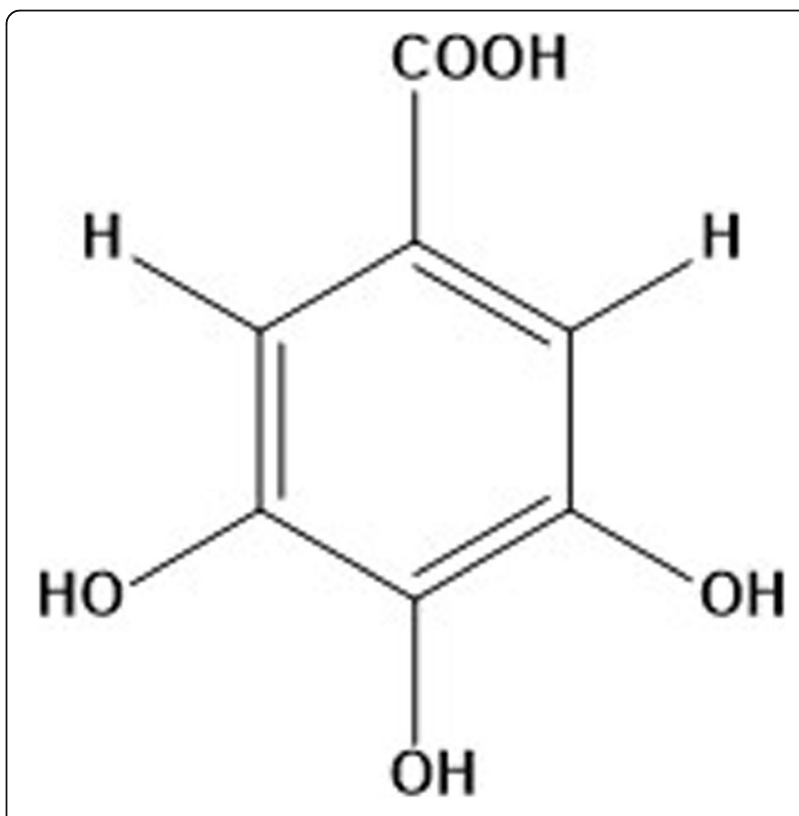

Fig. 1 Chemical structure of gallic acid (3,4,5-trihydroxybenzoic acid) 
Table 1 Percentage cell viability of gallic acid isolated from the fruit of Terminalia chebula by the MTT assay on HeLa cells

\begin{tabular}{ll}
\hline Concentration $(\mu \mathrm{g} / \mathrm{ml})$ & \% cell viability \\
\hline 100 & $40.51 \pm 1.31$ \\
50 & $59.02 \pm 1.73$ \\
25 & $66.51 \pm 0.35$ \\
12.5 & $70.15 \pm 1.25$ \\
6.25 & $82.11 \pm 0.75$ \\
3.12 & $96.45 \pm 1.79^{*}$ \\
1.56 & $96.98 \pm 2.36^{*}$ \\
0.78 & $98.67 \pm 3.03^{*}$ \\
\hline
\end{tabular}

Results are expressed as mean \pm SEM of six experiments

*Statistical significance $(P<0.05)$ evaluated using Student's $t$ test

Gallic acid showed moderate toxicity at the highest concentration $(100 \mu \mathrm{g} / \mathrm{ml})$ tested. $\mathrm{IC}_{50}$ value is found to be $72.68 \pm 2.08 \mu \mathrm{g} / \mathrm{ml}$. Cell viability greater than $90 \%$ is required to analyze the comet assay. Since the aim of the study was to evaluate the antigenotoxic activity of the compound, the lowest non-toxic concentration was chosen, i.e., $3.12 \mu \mathrm{g} / \mathrm{ml}$ for the isolated phenolic compound.

\subsection{Antigenotoxic effects of gallic acid isolated from the} fruit of Terminalia chebula by comet assay on HeLa cells Alkaline comet assay was implemented to evaluate the antigenotoxic effect of isolated compounds on HeLa cells. Comet length, tail length, and \% tail DNA (\% DNA in the tail of the comet) were measured using the software CometScore. Figure 2 shows the representative images for DNA damage in HeLa cells treated with $50 \mu \mathrm{M}$ $\mathrm{H}_{2} \mathrm{O}_{2}$ and the isolated phenolic compound. Before exposure to mutagen (hydrogen peroxide), the cells were incubated with the non-toxic concentration of isolated compounds for $1 \mathrm{~h}$. The cells were then exposed to different concentration of $\mathrm{H}_{2} \mathrm{O}_{2}$ and incubated for different time periods to find the suitable concentration of $\mathrm{H}_{2} \mathrm{O}_{2}$. Since the cells treated with $50 \mu \mathrm{M} \mathrm{H}_{2} \mathrm{O}_{2}$ for 15 min were found to be a suitable concentration to induce a high level of DNA damage, it was chosen for further studies.
Table 2 shows the data for the antigenotoxicity assessment. A total of 100 cells were evaluated per sample for comet length, tail length, and \% tail DNA measurement. The percentage of DNA in the tail at $50 \mu \mathrm{M} \mathrm{H} \mathrm{H}_{2} \mathrm{O}_{2}$ was $20.2 \pm 2.18$. The percentage of DNA damage was found to decrease as shown by a decrease in \% tail DNA, by incubation with the isolated compound. The tail length is the distance of DNA migration from the center of the head, which shows the extent of DNA damage. DNA tail length was found to be higher when the cells were exposed to hydrogen peroxide. DNA tail length for hydrogen peroxide-exposed cells was around $25.5 \pm 2.14$, whereas in cells pre-treated with isolated compound tail length was reduced to $9.8 \pm 1.4$. However, tail length for positive control ascorbic acid was $4.2 \pm 1.02$. \% tail DNA for the isolated compound was observed to be $8.7 \pm 1.3$. Overall, the result indicated that the compound showed significant protective abilities against hydrogen peroxideinduced DNA damage in HeLa cells at a concentration of $3.12 \mu \mathrm{g} / \mathrm{ml}$.

\section{Discussion}

The present study is focused on a promising DNA protective activity of isolated phenolic compound, gallic acid, from Terminalia chebula on cervical cancer cell. In this study, we examined the antigenotoxic potential of gallic acid against DNA damage induced by hydrogen peroxide. The compound was examined for cytotoxic activity in HeLa cell lines by MTT assay. For antigenotoxic activity study, the isolated phenolic compound was added to cells $1 \mathrm{~h}$ before administration of the stressinducing agent. The antigenotoxic activity of the isolated phenolic compounds was confirmed from the decreased hydrogen peroxide-induced DNA damage in HeLa cells as evaluated by comet assay.

Many methods are available for evaluating antigenotoxic activity, and those methods vary substantially in terms of complexity and chemistry. The comet assay measures the effectiveness of the compounds to protect cells from genotoxic damage [14]. In vitro pre-treatment of HeLa cells with gallic acid is very effective in preventing induced oxidative DNA damage. Even low

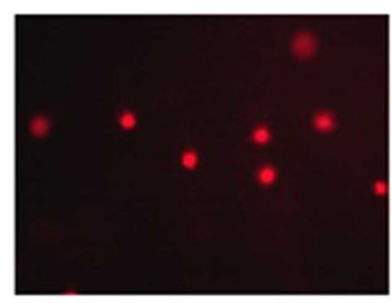

A

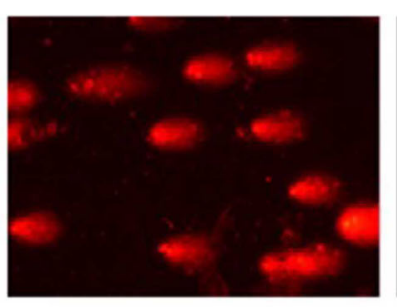

B

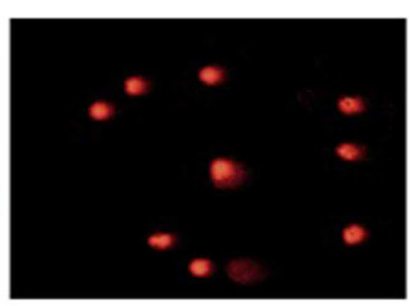

C

Fig. 2 Representative photographs depict the extent of DNA damage in HeLa cells treated with control and isolated compound from Terminalia chebula. a Untreated HeLa cells. b Control (HeLa cells treated with $50 \mu \mathrm{M} \mathrm{H}_{2} \mathrm{O}_{2}$ ). c Control + isolated compound 
Table 2 Level of DNA damage in normal, control, and phenolic compound isolated from Terminalia chebula on HeLa cell

\begin{tabular}{llll}
\hline Sample & Comet length $(\mu \mathrm{m})$ & Tail length $(\mu \mathrm{m})$ & $\%$ tail DNA \\
\hline Untreated HeLa & $28.85 \pm 2.4$ & $3.5 \pm 0.08$ & $4.1 \pm 0.2$ \\
$\mathrm{H}_{2} \mathrm{O}_{2}$ & $91.37 \pm 12.2^{*}$ & $25.5 \pm 2.14^{*}$ & $20.2 \pm 2.18^{*}$ \\
Isolated compound & $77.6 \pm 4.33^{*}$ & $9.8 \pm 1.4^{*}$ & $8.7 \pm 1.3^{*}$ \\
Ascorbic acid & $21.4 \pm 1.3^{*}$ & $4.2 \pm 0.03^{*}$ & $4.3 \pm 0.08$ \\
\hline
\end{tabular}

Results are expressed as mean $\pm \operatorname{SEM}(n=6)$. Statistical significance $(P)$ calculated by one-way ANOVA using SPSS 20.0. ${ }^{*} P<0.05$ relative to untreated control

concentration such as $3.12 \mu \mathrm{g} / \mathrm{ml}$ gallic acid provides a large effect. Untreated cells showed no significant DNA tails.

Many authors have reported that the increased antigenotoxic potential of isolated compounds may be because isolated phenolic compounds increase the cell's antioxidant capacity. Antioxidant capacity of compounds is associated with the following mechanism such as scavenging reactive oxygen species, donating hydrogen atoms or electrons, chelating metal cations, and enhancing the production of antioxidant enzymes and thus acting at a prevention level [5, 18, 24]. The beneficial effects of gallic acid have been attributed to their antioxidant properties. Gallic acid emerged as the strongest antioxidant in wellknown assays like DPPH assay, Trolox equivalent antioxidant capacity assay (TEAC I-III), total radical-trapping antioxidant parameter assay (TRAP), photochemiluminescence assay (PCL), and ferric reducing ability of plasma assay (FRAP) [3]. Our results are in agreement with the previous report on the cytotoxicity study of gallic acid on HeLa cell [23]. Also, to the best of our knowledge, this is the first study to describe the antigenotoxicity of gallic acid on HeLa cell. However, Ferk et al. have investigated by the experiments with rats that gallic acid reduces oxidatively damaged DNA in the lymphocytes, liver, colon, and lungs. Gallic acid protects these organs against $\gamma$ irradiation-induced strand breaks and formation of oxidatively damaged DNA bases [7]. Gandhi and crew have evaluated in in vivo studies that administration of gallic acid to animal prior to whole body radiation exposure reduced the peroxidation of lipids and the damage to the cellular DNA [8].

At this stage, it is not possible to say the exact mechanism(s) behind the antigenotoxic activity. It is possible to hypothesis that observed antigenotoxic potential of isolated phenolic compound could be assigned synergistic action of other mechanism such as (i) restriction of penetration of the toxins into the cells, (ii) direct inactivation of toxins by scavenging, (iii) stimulation of detoxification, (iv) cytotoxicity increase or decrease, (v) stimulation of DNA repair enzymes, and (vi) structureactivity relationship, $[6,11,15]$. The observed protective effect of the compound towards HeLa cell line may correspond to a synergic participation of the abovesaid mechanism(s).

Taken together, it has been estimated that the daily intake of gallic acid via food consumption may improve the health status of individuals under oxidative stress. Since gallic acid is contained in a large variety of foods, it is very easy to increase its daily intake by dietary measures.

\section{Conclusion}

In conclusion, gallic acid, which occurs in many plantderived foods, reduces the DNA damage induced by hydrogen peroxide in HeLa cell. Further investigations are necessary for a better understanding of mechanisms underlying the antigenotoxic effect of gallic acid on HeLa cell.

\section{Supplementary information}

Supplementary information accompanies this paper at https://doi.org/10 1186/s43088-019-0017-9.

Additional file 1: Figure S1. Supplementary Figure 1.

Additional file 2: Figure S2. Supplementary Figure 2.

Additional file 3: Figure S3. Supplementary Figure 3.

\section{Abbreviations}

DMEM: Dulbecco's modified Eagle medium; DMSO: Dimethyl sulfoxide; DNA: Deoxyribonucleic acid; FBS: Fetal bovine serum; H2O2: Hydrogen peroxide; LMPA: Low melting point agarose; MTT: 3-(4,5-Dimethylthiazol-2yl)-2,5-diphenyltetrazolium bromide; Na2EDTA: Disodium

ethylenediaminetetraacetate dihydrate; $\mathrm{NaCl}$ : Sodium chloride; $\mathrm{NaOH}$ : Sodium hydroxide; NMA: Normal melting point agarose; ROS: Reactive oxygen species; SEM: Standard error of the mean; TLC: Thin-layer chromatography

\section{Acknowledgements}

We acknowledge the Council of Scientific and Industrial Research, India, for granting fellowship in the form Junior Research Fellowship. We are also thankful to Mr. Vishnu, Central University of Kerala, Kerala, India, and Mrs. Vidya, University of Calicut, Kerala, India, for the service provided for cell line studies.

\section{Authors' contributions}

SS and SK conceived of the presented idea. JJ performed the extraction procedure. ATM helped the cell culture work. DAT contributed to the interpretation of the results. SK wrote the manuscript with support from SAP. All authors discussed the results and contributed to the final manuscript. SS supervised the project. All authors read and approved the final manuscript.

\section{Funding}

Not applicable.

Availability of data and materials

Not applicable.

Ethics approval and consent to participate

Not applicable.

Consent for publication

Not applicable.

Competing interests

The authors declare that they have no competing interests. 
Received: 3 July 2019 Accepted: 9 October 2019

Published online: 27 November 2019

\section{References}

1. Akyl D, Konuk M (2015) Detection of genotoxicity and mutagenicity of chlorthiophos using micronucleus, chromosome aberration, sister chromatid exchange, and Ames tests. Environ toxicol 30:937-945

2. Auddy B, Ferreira M, Blasina F, Lafon L, Arredondo F, Dajas F, Tripathi PC, Seal T, Mukherjee B (2003) Screening of antioxidant activity of three Indian medicinal plants, traditionally used for the management of neurodegenerative diseases. J Ethnopharmacol 84:131-138

3. Badhani B, Sharma N, Kakkar R (2015) Gallic acid : a versatile antioxidant with promising therapeutic and industrial applications. RSC Adv 5:27540-27557

4. Benhusein G, Mutch E, Aburawi S, Williams F (2010) Genotoxic effect induced by hydrogen peroxide in human hepatoma cells using comet assay. Libyan J Med 5:4637

5. Cabarkapa A, Zivkovic L, Zukovec D, Djelic N, Bajic V, Dekanski D, SpremoPotparevic B (2014) Protective effect of dry olive leaf extract in adrenaline induce DNA damage evaluated using in vitro comet assay with human peripheral leukocytes. Toxicol in Vitro 28:451-456

6. Drosopoulou E, Vlastos D, Efthimiou I, Kyrizaki P, Tsamadou S, Anagnostopoulou M, Kofidou D, Gavriilidis M, Mademtzoglou D, MavraganiTsipidou P (2018) In vitro and in vivo evaluation of the genotoxic and antigenotoxic potential of the major Chios mastic water constituents. Sci Rep 8:12200

7. Ferk F, Chakraborty A, Jager W, Kundi M, Bichler J, Misik M, Wagner KH, Grasl-Kraupp B, Sagmeister S, Haidinger G, Hoelzl C (2011) Potent protection of gallic acid against DNA oxidation: results of human and animal experiments. Mutat Res-Fund Mol M 715:61-71

8. Gandhi NM, Nair CKK (2005) Protection of DNA and membrane from gamma radiation induced damage by gallic acid. Mol cell biochem 278 : $111-117$

9. Kalita S, Kumar G, Karthik RKVB (2012) In vitro antioxidant and DNA damage inhibition activity of aqueous extract of Lantana camara L.(Verbenaceae) leaves. Asian Pac J Trop Biomed 2:S1675-S1679

10. Kang C, Lee H, Yoo YS, Hah DY, Kim CH, Kim E, Kim JS (2013) Evaluation of oxidative DNA damage using an alkaline single cell gel electrophoresis (SCGE) comet assay, and the protective effects of N-acetylcysteine amide on zearalenone-induced cytotoxicity in chang liver cells. Toxicol Res 29:43

11. Kilani-Jaziri S, Bhouri W, Skandrani I, Limem I, Chekir-Ghedira L, Ghedira K (2011) Phytochemical, antimicrobial, antioxidant and antigenotoxic potentials of Cyperus rotundus extracts. S Afr J Bot 77:767-776

12. Koppenn G, Azqueta A, Pourrut B, Brunborg G, Collins AR, Langie SA (2017) The next three decades of the comet assay: a report of the $11^{\text {th }}$ International Comet Assay Workshop. Mutagenesis 32:397-408

13. Leandro LF, Munari CC, Sato VLFL, Alves JM, de Oliveira PF, Mastrocola DFP, Martins SDPL, da Silva MT, de Oliveira Al, Tozatti MG, Cunha WR (2013) Assessment of the genotoxicity and antigenotoxicity of (+)-usnic acid in V79 cells and Swiss mice by the micronucleus and comet assays. Mutat Res Genet Toxicol Environ Mutagen 753:101-106

14. Lee-Manion AM, Price RK, Strain JJ, Dimberg LH, Sunnerheim K, Welch RW (2009) In vitro antioxidant activity and antigenotoxic effects of avenanthramides and related compounds. J Agric Food Chem 57: 10619-10624

15. Prajitha V, Thoppil JE (2016) Genotoxic and antigenotoxic potential of the aqueous leaf extracts of Amaranthus spinosus Linn. using Allium cepa assay. S Afr J Bot 102:18-25

16. Prieto AM, dos Santos AG, Oliveira APS, Cavalheiro AJ, Silva DH, Bolzani VS, Varanda EA, Soares CP (2013) Assessment of the chemopreventive effect of casearin B, a clerodane diterpene extracted from Casearia sylvestris (Salicaceae). Food Chem Toxicol 53:153-159

17. Ramos AA, Lima CF, Pereira-Wilson C (2011) DNA damage protection and induction of repair by dietary phytochemicals and cancer prevention: what do we know? Selected Topics in DNA Repair. Intech Open:237-270

18. Sabahi Z, Soltani F, Moein M (2018) Insight into DNA protection ability of medicinal herbs and potential mechanisms in hydrogen peroxide damages model. Asian Pac J Trop Biomed 8:120

19. Sarria-Villa RA, Gallo-Corredor JA, Paez MI (2017) Isolation of catechin and gallic acid from Colombian bark of Pinus patula. Chem Sci J 8:174
20. Shabrina R, Elya B, Noviani A (2018) Antioxidant activities of fractions from ethyl acetate extracts of garcinia fruticosa lauterb leaves. Int J App Pharm 10:44-50

21. Swamy SMK, Tan BKH (2000) Cytotoxic and immunopotentiating effects of ethanolic extract of Nigella sativa L. seeds. J Ethnopharmacol 70:1-7

22. Villavicencio ALCH, Araujo MM, Marin-Huachaca NS, Mancini-Filho J, Delincee H (2004) Identification of irradiated refrigerated poultry with the DNA comet assay. Radiat Phys Chem 71:189-191

23. Zhao B, Hu M (2013) Gallic acid reduces cell viability, proliferation, invasion and angiogenesis in human cervical cancer cells. Oncol Lett 6:1749-1755

24. Zivkovic L, Borozan S, Cabarkapa A, Topalovic D, Ciptasari U, Bajic V, Spremo Potparevic B (2017) Antigenotoxic properties of Agaricus blazei against hydrogen peroxide in human peripheral blood cells. Oxid Med Cell Longev 2017:1-9

\section{Publisher's Note}

Springer Nature remains neutral with regard to jurisdictional claims in published maps and institutional affiliations.

\section{Submit your manuscript to a SpringerOpen ${ }^{\circ}$ journal and benefit from:}

- Convenient online submission

- Rigorous peer review

- Open access: articles freely available online

- High visibility within the field

- Retaining the copyright to your article

Submit your next manuscript at $\boldsymbol{\nabla}$ springeropen.com 